https://jurnal.univpgri-

palembang.ac.id/index.php/luminous

\title{
PEMBELAJARAN KONSTEKSTUAL SECARA DARING BERBASIS PROYEK UNTUK MENINGKATKAN PRESTASI BELAJAR PESERTA DIDIK KELAS XI
}

\author{
Firman Ma'ruf ${ }^{1}$, Agus Rohman $^{2(*)}$ \\ ${ }^{1}$ Program Studi Pendidikan Fisika, STKIP AI Hikamah \\ Surabaya, Indonesia \\ maruf10121998@gmail.com \\ ${ }^{2}$ Program Studi Pendidikan Fisika, STKIP Al Hikmah \\ Surabaya, Indonesia \\ agus.rohman5ure@gmail.com
}

Received: 1401 2021. Accepted: 0902 2021. Published: 15022021

\begin{abstract}
Abstrak
Masa pandemic covid 19 belum berakhir, tentu hal ini menjadi masalah yang perlu dicarikan alternatif solusinya, khusunya dalam mengajarkan ilmu fisika pada peserta didik. Mengingat mata pelajaran fisika tidak hanya mengajarkan pada produk, namun juga pada aspek psikomotor dan afektif peserta didik. Tujuan penelitian ini adalah mengidentifikasi efektivitas model pembelajaran kontekstual berbasis proyek selama pembelajaran fisika dilakukan secara daring. Metode penelitian yang digunakan adalah metodep penelitian tindakan kelas dengan 2 siklus. Siklus pertama menggunakan model pembelajaran kontekstual, sedangkan siklus kedua menggunakan model pembelajaran kontekstual berbasis proyek. Keefektifan model pembelajaran yang diukur adalah aktivitas guru, aktivitas peserta didik, dan prestasi belajar peserta didik. Hasil penelitian menunjukkan bahwa pada siklus 1, aktifitas guru, aktivitas peserta didik, dan prestasi belajar peserta didik ditinjau dari yang tuntas dan tidak tuntas masing-masing memiliki rerata $65 \%, 66 \%$, peserta didik tuntas 13 orang, dan yang tidak tuntas 23 orang. Siklus 2 diperoleh hasil aktifitas guru, aktivitas peserta didik, prestasi belajar yang tuntas, dan peserta didik yang tidak tuntas masing-masing sebagai berikut $85 \%, 86 \%$, 31 orang, dan 5 orang. Berdasarkan hasil penelitian yang diperoleh, dapat disimpulkan bawah model pembelajaran kontekstual berbasis proyek efektif digunakan untuk meningkatkan prestasi belajar peserta didik selama masa pandemic covid 19 yang dilakukan secara daring.
\end{abstract}

Kata Kunci: Kontekstual, proyek, prestasi belajar

\section{(C) 2021 Pendidikan Fisika FKIP UPGRI Palembang}

\section{PENDAHULUAN}

Hakikat fisika adalah ilmu pengetahuan yang mempelajari gejala-gejala melalui serangkaian proses yang dikenal dengan proses ilmiah yang dibangun atas dasar sikap ilmiah dan hasilnya terwujud sebagai produk ilmiah yang tersusun atas tiga komponen terpenting berupa konsep, prinsip, dan teori yang berlaku secara universal (Trianto, 2010). Dari kutipan diatas, dapat kita ketahui bahwa hasil belajar yang diharapkan pada pembelajaran fisika sejatinya merupakan penguasaan konsep, prinsip, dan teori 
universal. Pembelajaran fisika selama ini terjebak pada rutinitas metode yang bersifat kapur dan tutur (chalk and talk), dengan demikian proses pembelajaran khususnya mata pelajaran fisika di sekolah belum memberikan hasil sebagaimana yang diharapkan (Hidayah \& Yuberti, 2018).

Untuk bisa mengatasi masalah terkait ilmu pengetahuan alam dan teknologi dalam kehidupan, maka siswa dalam proses belajarnya peserta didik harus dilatih berpikir untuk memecahkan permasalahan autentik disekitarnya. Dengan kata lain pembelajaran kontekstual dapat membantu siswa menyelesaikan permasalahan autententik disekitarnya. Pendidikan fisika diarahkan untuk mencari tahu dan berbuat sehingga dapat membantu peserta didik untuk memperoleh pemahaman yang lebih mendalam tentang alam sekitar (Rahayuningsih dan Dwiyanto, 2005).

Wabah Covid-19 yang melanda Dunia, telah memberikan tantangan tersendiri bagi lembaga pendidikan, tak terkecuali sekolah menengah atas. Untuk mengantisipasi penyebaran virus corona, pemerintah mengeluarkan beberapa kebijakan yang diantaranya berupa PSBB (Pembetasan sosial berskala besar), serta penerapan protokol kesehatan. Keadaan ini mengharuskan masyarakat untuk tetap berada dirumah, beribadah, berkerja dan belajar di rumah. Kondisi ini menuntut inovasi dari lembaga pendidikan dalam melaksanakan proses pembelajaran. Bentuk inovasi kegiatan pembelajaran tersebut diantaranya ialah dengan melakukan pembelajaran secara online atau daring (dalam jaringan). Pembelajaran online merupakan bentuk pembelajaran/pelatihan jarak jauh yang memanfaatkan teknologi telekomunikasi dan informasi, misalnya internet, CD-ROOM (secara langsung dan tidak langsung) (Molinda, 2005).

Dalam pelaksanaannya pembelajaran daring dianggap kurang efektif dan tidak bermakna, sehingga sulit untuk menerapkan pembelajaran kontekstual melalui pembelajran daring. Permasalahan diatas ditambah dengan penurunan partisipasi siswa dalam pembelajaran yang dilatarbelakangi berbagai persoalan. Dengan adanya keterbatasan teknologi dan gagap teknologi, prestasi belajar peserta didikpun sulit mengalami peningkatan.
Hal tersebut diatas menimpa kelas X MIA 1 SMA Negeri 18 Surabaya. Oleh karena itu, guru dalam penelitian ini berusaha mencari solusi untuk meningkatkan partisipasi dan prestasi belajar peserta didik dalam pembelajaran daring.

Permasalahan terkait dengan kurangnya prestasi belajar pesera didik di kelas X MIA 1 SMA Negeri 18 Surabaya dapat diatasi dengan pembelajaran kontekstual daring berbasis proyek. Pembelajaran berbasis proyek memberikan peluang kepada peserta didik untuk mempelajari konsep secara mendalam dan membuatnya berlatih memecahkan permasalahan kontekstual disekitarnya. Pembelajaran berbasis proyek merupakan investigasi mendalam tentang sebuah topik dari dunia nyata (Sucilestari dan Arizona, 2018). Dengan pembelajaran berbasis proyek, peserta didik akan melakukan pengamatan secara langsung terhadap fenomena fisis yang ada disekitarnya sehingga membuat pembelajaran lebih bermakna.

Penelitian ini dilakukan dikelas XI MIA 1 pada materi fluida statis. Adapun proyek yang dapat dibuat dalam materi pembelajaran ini sangatlah variatif, mengingat setiap hari kita berinteraksi dengan fluida. Proyek dapat dibuat sederhana seperti menganalisis tekanan fluida pada bak mandi, botol, gelas, atau kolam. Proyek juga dapat dibuat rumit dan aplikatif seperti pembuatan alat pendeteksi banjir, pompa air alami dan lain sebagainya

\section{METODE}

Jenis penelitian ini adalah penelitian tindakan kelas. Penelitian berjalan sesuai dengan format penelitian tindakan kelas, yang terdiri dari dua siklus tindakan atau lebih. Ada empat tahapan penting dalam setiap siklus penelitian tindakan, yaitu: perencanaan, pelaksanaan, pengamatan, dan refleksi (Arikunto, dkk. 2008: 20). Siklus kedua dapat dilaksanakan setelah dilakukan perbaikan-perbaikan pada siklus pertama.

Siklus pertama dilaksanakan berdasarkan observasi pada kondisi awal dan terdiri dari tiga pertemuan. Pertemuan pertama bertujuan untuk menyampaikan materi pembelajaran, pertemuan berikutnya digunakan untuk pengerjaan tugas dan 
diskusi dan pertemuan terakhir digunakan untuk menguji pemahaman siswa dengan mempresentasikan proyek yang telah dibuat melalui video. Tindakan pada siklus kedua dilaksanakan berdasarkan hasil observasi pada siklus pertama. Tindakan pada siklus kedua juga terdiri dari tiga pertemuan. Perbedaan siklus pertama dengan siklus kedua terletak pada penugasan. Pada siklus pertama peserta didik hanya ditugaskan untuk membuat proyek yang sederhana sebagai pembuktian tanpa analisis data, sedangkan pada siklus kedua peserta didik ditugaskan untuk membuat proyek dengan data dan analisisnya. Adapun tahapan pada setiap siklus adalah sebagai berikut.

\section{Perencanaan}

Tahap ini berkaitan dengan persiapan sebelum pembelajaran. Perencanaan akan dijadikan sebagai acuan dalam melakukan tindakan. Perencanaan meliputi kegiatan merancang rencana pembelajaran, menyiapkan media yang dibutuhkan, membuat instrumen penilaian, soal, lembar observasi, dan lain sebagainya. Proses ini dilakukan supaya kegiatan penelitian bisa berjalan dengann efektif dan efisien. Tahap perencanaan pada siklus pertama didasarkan pada observasi awal. Perencanaan tindakan pada siklus kedua didasarkan pada hasil observasi dan refleksi pada siklus pertama.

\section{Pelaksanaan}

Pelaksanaan yaitu penerapan rancangan penelitian, kegiatan ini meliputi tindakan yang dilakukan dalam kegiatan pembelajaran. Tindakan dilaksanakan sesuai dengan rencana pembelajaran yang dibuat pada tahap sebelumnya. Tahap ini berupa proses interaksi guru dan peserta didik dalam kegiatan pembelajaran. Pada penelitian tidakan kelas kali ini, tindakan dilaksanakan secara daring, sehingga indikator penelitian akan disesuaikan dengan kegiatan pembelajaran daring.

\section{Pengamatan}

Pengamatan merupakan kegiatan mengamati yang dilaksanakan oleh pengamat. Pengamat bukanlah peneliti, pengamat akan mencatat sedikit demi sedikit apa yang terjadi. Pemilihan penggunaan jasa pengamat ini bertujuan agar peneliti dapat memperoleh data yang akurat untuk perbaikan siklus selanjutnya. Pada penelitian ini yang menjadi fokus pengamatan ialah meliputi: (1) Kinerja guru dalam melaksanakan pembelajaran, (2) Aktivitas peserta didik saat pembelajaran, (3) Prestasi belajar peserta didik.

Refleksi

Refleksi merupakan kegiatan yang dilaksanakan untuk mengemukakan kembali apa yang sudah dilakukan. Kegiatan refleksi ini dilakukan oleh peneliti setelah selesai melakukan tindakan pada masing-masing siklus. Pada siklus pertama kegiatan refleksi bertujuan untuk menemukan hal-hal yang sudah sesuai dengan rancangan pembelajaran dan mengetahui secara mendalam mengenai hal-hal yang masih perlu diperbaiki pada siklus berikutnya. Kegiatan refleksi pada siklus kedua juga bertujuan untuk mengetahui hal-hal yang perlu diperbaiki pada siklus berikutnya. Jika tujuan penelitian telah tercapai pada siklus kedua, peneliti bisa langsung mengambil kesimpulan sesuai dengan hasil penelitian. Jika tujuan penelitian tindakan kelas belum tercapai pada siklus kedua maka penelitian tindakan dilanjutkan pada siklus selanjutnya.

Analisis data hasil observasi dalam bentuk deskriptif kuantitatif yaitu data yang berwujud angkaangka hasil perhitungan atau pengukuran dapat di proses dengan cara dijumlahkan, dibandingkan dengan yang tersedia dan diperoleh hasil persentase (Arikunto, dkk. 2008: 20). Dari hasil observasi yang telah didapatkan, kemudian diolah dengan cara tabulansi dan dianalisis dengan menggunakan teknik persentase. Kemudian hasil persentase diklasifikasikan dalam kriteria berikut.

$$
\begin{aligned}
& \text { Baik }=76-100 \% \\
& \text { Cukup }=60-75 \% \\
& \text { Kurang }<60 \% \\
& \text { (Arikunto, 1998) }
\end{aligned}
$$




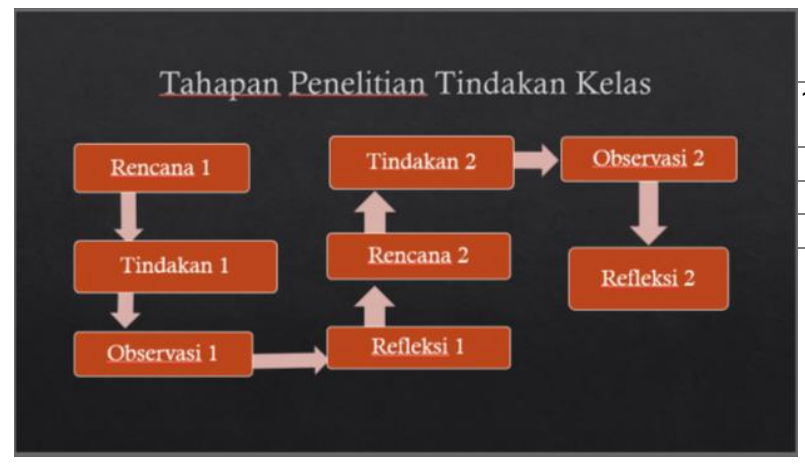

Gambar 1. Tahapan penelitian Tindakan kelas

Penelitian tindakan kelas ini dilaksanakan di SMA Negeri 18 Surabaya dengan objek penelitian peserta didik kelas XI MIA 1 yang terdiri dari 36 peserta didik. Penelitian dilaksanakan pada bulan oktober 2020. Populasi adalah keseluruhan subjek penelitian, sehingga populasi dari penelitian ini ialah peserta didik kelas XI MIA 1 SMA Negeri 18 Surabaya. Sampel pada penelitian ini merupakan seluruh populasi, hal tersebut dikarenakan populasi kurang dari 100. Apabila subyek kurang dari 100, lebih baik diambil semua sehingga penelitiannya merupakan penelitian populasi (Arikunto 1998).

\section{HASIL DAN PEMBAHASAN}

\section{Siklus 1: Aktivitas Guru}

Tabel 1. Hasil observasi aktifitas guru pada siklus 1

\begin{tabular}{|c|c|c|c|c|}
\hline \multirow{2}{*}{ No } & \multirow[t]{2}{*}{ Indikator yang diamati } & \multicolumn{3}{|c|}{ Pertemuan } \\
\hline & & 1 & 2 & 3 \\
\hline 1. & $\begin{array}{l}\text { Kesiapan pendidik dalam } \\
\text { melaksanakan pembelajaran } \\
\text { daring }\end{array}$ & 3 & 3 & 4 \\
\hline 2. & $\begin{array}{l}\text { Ketersediaan materi yang } \\
\text { diajarkan }\end{array}$ & 3 & 3 & 3 \\
\hline 3. & Memotivasi peserta didik & 2 & 2 & 3 \\
\hline 4. & $\begin{array}{l}\text { Menyiapkan indikator } \\
\text { pembelajaran dan tujuan } \\
\text { pembelajaran }\end{array}$ & 2 & 3 & 3 \\
\hline 5. & $\begin{array}{l}\text { Menyampaikan materi } \\
\text { pembelajran dengan } \\
\text { menggunakan media } \\
\text { pembelajaran }\end{array}$ & 2 & 3 & 3 \\
\hline 6. & $\begin{array}{l}\text { Mengajak peserta didik } \\
\text { melakukan percobaan dengan } \\
\text { membuat proyek }\end{array}$ & 1 & 3 & 3 \\
\hline 7. & $\begin{array}{l}\text { Membimbing peserta didik } \\
\text { dalam melaksanakan LKPD }\end{array}$ & 1 & 3 & 3 \\
\hline 8. & $\begin{array}{l}\text { Membimbing peserta didik } \\
\text { dalam menuntaskan LKPD }\end{array}$ & 1 & 2 & 3 \\
\hline 9. & $\begin{array}{l}\text { Membimbing peserta didik untuk } \\
\text { menyimpulkan materi yang } \\
\text { dipelajari }\end{array}$ & 3 & 3 & 3 \\
\hline
\end{tabular}

\begin{tabular}{ccccc}
\hline $\begin{array}{l}\text { Memberikan evaluasi } \\
\text { peserta didik }\end{array}$ & kepada & 2 & 2 & 3 \\
\hline Jumlah skor & 20 & 27 & 31 \\
\hline Skor maksimal & 40 & 40 & 40 \\
\hline Presentase (\%) & $50 \%$ & $68 \%$ & $78 \%$ \\
\hline
\end{tabular}

Aktivitas peserta didik

Tabel 2. Tabel observasi peserta didik pada siklus 1

\begin{tabular}{|c|c|c|c|c|}
\hline \multirow[t]{2}{*}{ No. } & \multirow[t]{2}{*}{ Indikator yang diamati } & \multicolumn{3}{|c|}{ Pertemuan } \\
\hline & & 1 & 2 & 3 \\
\hline 1 & $\begin{array}{l}\text { Kesiapan peserta didik } \\
\text { dalam mengikuti } \\
\text { pembelajaran daring }\end{array}$ & 2 & 3 & 3 \\
\hline 2 & $\begin{array}{l}\text { Memberikan tanggapan } \\
\text { terhadap materi yang } \\
\text { diberikan }\end{array}$ & 2 & 2 & 3 \\
\hline 3 & $\begin{array}{l}\text { Memperhatikan materi } \\
\text { yang diasampaikan oleh } \\
\text { guru }\end{array}$ & 2 & 2 & 3 \\
\hline 4 & $\begin{array}{l}\text { Melakukan percobaan } \\
\text { sederhana dengan } \\
\text { membuat proyek }\end{array}$ & 2 & 3 & 3 \\
\hline 5 & $\begin{array}{l}\text { Melaksanakan LKPD } \\
\text { yang telah diberikan }\end{array}$ & 2 & 3 & 3 \\
\hline 6 & $\begin{array}{l}\text { Mengajukan pertanyaan } \\
\text { atau tanggapan }\end{array}$ & 2 & 3 & 3 \\
\hline 7 & $\begin{array}{l}\text { Mengerjakan proyek yang } \\
\text { diberikan oleh guru } \\
\text { hingga tuntas }\end{array}$ & 3 & 3 & 3 \\
\hline 8 & $\begin{array}{l}\text { Membuat kesimpulan } \\
\text { pada materi yang } \\
\text { dipelajari }\end{array}$ & 2 & 3 & 4 \\
\hline 9 & Mengikuti kegiatan evalusi & 3 & 3 & 3 \\
\hline & Jumlah skor & 20 & 24 & 29 \\
\hline & Skor maksimal & 36 & 36 & 36 \\
\hline & Presentase (\%) & $55 \%$ & $67 \%$ & $77 \%$ \\
\hline
\end{tabular}

Prestasi belajar peserta didik

Tabel 3. Hasil belajar pada siklus 1

\begin{tabular}{clc}
\hline No & \multicolumn{1}{c}{ Aspek yang diamati } & Hasil \\
\hline 1 & Skor tertinggi & 90 \\
\hline 2 & Skor terendah & 52 \\
\hline 3 & Jumlah peserta didik & 36 \\
\hline 4 & Banyaknya peserta didik yang tuntas & 13 \\
\hline 5 & Banyaknya peserta didik yang tidak tuntas & 23 \\
\hline
\end{tabular}


Siklus II

Aktivitas guru

Tabel 4. Aktivitas guru pada siklus II

\begin{tabular}{|c|c|c|c|c|}
\hline \multirow[t]{2}{*}{ No. } & \multirow[t]{2}{*}{ Indikator yang diamati } & \multicolumn{3}{|c|}{ Pertemuan } \\
\hline & & 4 & 5 & 6 \\
\hline 1. & $\begin{array}{l}\text { Kesiapan pendidik dalam } \\
\text { melaksanakan pembelajaran } \\
\text { daring }\end{array}$ & 3 & 4 & 4 \\
\hline 2. & $\begin{array}{l}\text { Ketersediaan materi yang } \\
\text { diajarkan }\end{array}$ & 3 & 3 & 4 \\
\hline 3. & Memotivasi peserta didik & 4 & 4 & 4 \\
\hline 4. & $\begin{array}{l}\text { Menyiapkan indikator } \\
\text { pembelajaran dan tujuan } \\
\text { pembelajaran }\end{array}$ & 4 & 4 & 4 \\
\hline 5. & $\begin{array}{l}\text { Menyampaikan materi } \\
\text { pembelajran dengan } \\
\text { menggunakan media } \\
\text { pembelajaran }\end{array}$ & 2 & 3 & 4 \\
\hline 6. & $\begin{array}{l}\text { Mengajak peserta didik } \\
\text { melakukan percobaan dengan } \\
\text { membuat proyek }\end{array}$ & 2 & 4 & 4 \\
\hline 7. & $\begin{array}{l}\text { Membimbing peserta didik } \\
\text { dalam melaksanakan LKPD }\end{array}$ & 2 & 3 & 4 \\
\hline 8. & $\begin{array}{l}\text { Membimbing peserta didik } \\
\text { dalam menuntaskan LKPD }\end{array}$ & 2 & 4 & 4 \\
\hline 9. & $\begin{array}{l}\text { Membimbing peserta didik } \\
\text { untuk menyimpulkan materi } \\
\text { yang dipelajari }\end{array}$ & 3 & 4 & 4 \\
\hline 10. & $\begin{array}{l}\text { Memberikan evaluasi kepada } \\
\text { peserta didik }\end{array}$ & 3 & 4 & 4 \\
\hline & Jumlah skor & 28 & 34 & 40 \\
\hline & Skor maksimal & 40 & 40 & 40 \\
\hline & Presentase (\%) & $70 \%$ & $85 \%$ & $100 \%$ \\
\hline
\end{tabular}

Aktivitas Siswa

Tabel 5. Aktivitas siswa siklus II

\begin{tabular}{clccc}
\hline No. & \multicolumn{1}{c}{ Indikator yang diamati } & \multicolumn{3}{c}{ Pertemuan } \\
\cline { 3 - 4 } & & 4 & 5 & 6 \\
\hline 1 & $\begin{array}{l}\text { Kesiapan peserta didik dalam } \\
\text { mengikuti pembelajaran } \\
\text { daring }\end{array}$ & 4 & 4 & 4 \\
\hline 2 & $\begin{array}{l}\text { Memberikan tanggapan } \\
\text { terhadap materi yang } \\
\text { diberikan }\end{array}$ & 3 & 3 & 4 \\
\hline 3 & $\begin{array}{l}\text { Memperhatikan materi yang } \\
\text { diasampaikan oleh guru }\end{array}$ & 3 & 3 & 4 \\
\hline 4 & $\begin{array}{l}\text { Melakukan percobaan } \\
\text { sederhana dengan membuat } \\
\text { proyek }\end{array}$ & 2 & 3 & 4 \\
\hline 5 & $\begin{array}{l}\text { Melaksanakan LKPD yang } \\
\text { telah diberikan }\end{array}$ & 2 & 3 & 4 \\
\hline 6 & $\begin{array}{l}\text { Mengajukan pertanyaan atau } \\
\text { tanggapan } \\
\text { Mengerjakan proyek yang } \\
\text { diberikan oleh guru hingga } \\
\text { tuntas }\end{array}$ & 4 & 4 & 4 \\
\hline $\begin{array}{l}\text { Membuat kesimpulan pada } \\
\text { materi yang dipelajari }\end{array}$ & 3 & 4 & 4 \\
\hline
\end{tabular}

\begin{tabular}{ccccc}
\hline 9 & Mengikuti kegiatan evalusi & 3 & 4 & 3 \\
\hline Jumlah skor & 26 & 32 & 35 \\
\hline Skor maksimal & 36 & 36 & 36 \\
\hline Presentase (\%) & $72 \%$ & $89 \%$ & $97 \%$
\end{tabular}

Prestasi belajar siswa

Tabel 6. Prestasi belajar peserta didik

\begin{tabular}{clc}
\hline No & \multicolumn{1}{c}{ Aspek yang diamati } & Hasil \\
\hline 1 & Skor tertinggi & 95 \\
\hline 2 & Skor terendah & 91 \\
\hline 3 & Jumlah peserta didik & 36 \\
\hline 4 & Banyaknya peserta didik yang tuntas & 31 \\
\hline 5 & $\begin{array}{l}\text { Banyaknya peserta didik yang tidak } \\
\text { tuntas }\end{array}$ & 5 \\
&
\end{tabular}

Pembelajaran daring berbasis proyek pada pembelajaran fisika dapat meningkatkan prestasi belajar peserta didik kelas XI MIA 1 SMA Negeri 18 Surabaya. Hal tersebut dapat dilihat dari ketuntasan belajar peserta didik yang mengalami peningkatan. Peningkatan prestasi belajar peserta didik dari siklus I (63\%) ke siklus II (86\%) sebesar 23\%. Peningkatan prestasi belajar tersebut ditunjang dengan peningkatan aktivitas guru dan peserta didik selama proses pembelajaran.

Pada siklus pertama peranan guru dalam pembelajaran berada dibawah setandar. Pada pertemuan pertama peranan guru hanya mencatatkan $50 \%$ dari indikator yang ada, sehingga masuk dalam kriteria kurang. Pada pertemuan kedua aktivitas guru mencatatkan $68 \%$ dari indikator yang ada, sehingga masuk dalam kategori cukup. Aktivitas guru pada pertemuan ke 3 siklus pertama mencatatkan $78 \%$ dari indicator yang ada, sehingga masuk kategori baik. Aktivitas peserta didik pada siklus pertama hanya mencatatkan 55\%, 67\% dan $77 \%$ dari indikator yang ada. Dengan hasil tersebut, pertemuan pertama masuk dalam kategori kurang, pertemuan kedua cukup dan pertemuan ketiga masuk dalam kategori baik. Dengan melihat data aktivitas guru dan peserta didik diatas, tidak mengherankan jika prestasi belajar peserta didik juga rendah. Dari 36 peserta didik $63 \%$ diantaranya dinyatakan tuntas dan $36 \%$ diantaranya belum tuntas. 
Pada siklus kedua peranan guru dalam pembelajaran mengalami peningkatan. Adapun aktivitas guru pada siklus kedua mencapai $70 \%, 85 \%$ dan $100 \%$ dari indikator yang ada, sehingga masuk dalam kategori baik. Peningkatan aktivitas guru disambut dengan baik oleh peserta didik sehingga aktivitas peserta didik pada siklus kedua juga meningkat. Pada siklus kedua aktivitas peserta didik mencapai $72 \%$, 89\% dan 97\%, sehingga masuk dalam kriteria baik. Adanya peningkatan positif pada aktivitas guru dan peserta didik mempengaruhi prestasi belajar yang diperoleh oleh peserta didik. Prestasi belajar peserta didik mengalami peningkatan signifikan dengan selisih $23 \%$ dari siklus pertama. Dari 36 peserta didik $86 \%$ diantaranya dinyatakan tuntas dan $14 \%$ diantaranya belum tuntas. Peserta didik yang dinyatakan belum tuntas pada siklus kedua merupakan peserta didik yang tidak dapat melaksanakan evaluasi pada pertemuan ke-6.

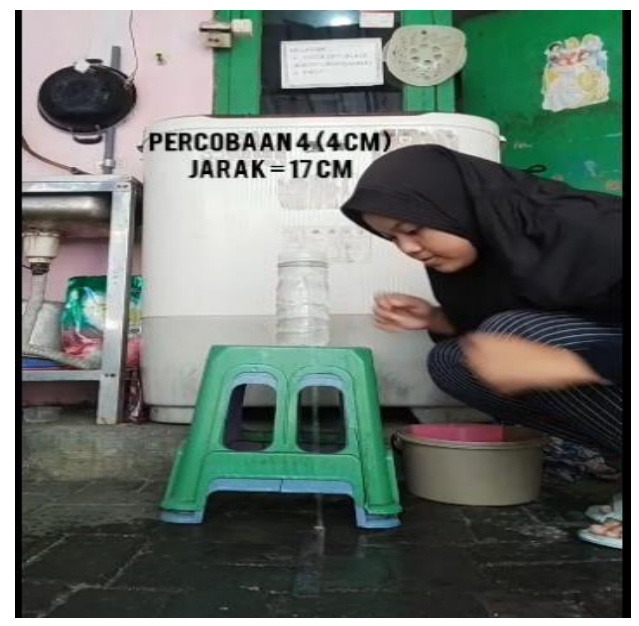

Gambar 2. Contok pelaksaan proyek pembelajaran

\section{SIMPULAN}

Model pembelajaran kontekstual daring berbasis proyek memungkinkan peserta didik untuk dapat memperoleh pengalaman belajar yang bermakna. Pengalaman belajar bermakna memungkinkan peserta didik untuk tetap mengingat materi pembelajaran yang dipelajari dalam jangka waktu yang panjang. Model pembelajaran ini juga dapat mengakomodasi pembelajaran student centered learning. Pada saat peserta didik membuat proyek, terdapat LKPD yang mengarahkan peserta didik untuk melakukan kegiatan pembelajaran secara mandiri. Model pembelajaran ini sangat cocok digunakan dimasa pandemi seperti sekarang. Peneliti menyarankan untuk melaksakan pembelajaran dengan model seperti ini dikala pandemi. Prangkat harus dibuat dengan seksama sehingga tujuan pembelajaran dapat tercapai secara maksimal.

\section{DAFTAR PUSTAKA}

Arikunto, Suharsimi dkk. 2008. Penelitian Tindakan Kelas. Jakarta: Sinar Grafika.

Arikunto. (1998). Metodologi Penelitian. [on-line] Tersedia: belajarstatistik.wordpress.com/ 2008/09/28/metodologi-penelitian [3 Maret 2014]

Depdikbud. (1999). Penelitian Tindakan Kelas. Jakarta: Depdikbud.

Hidayah, A., \& Yuberti, Y. (2018). Pengaruh Model Pembelajaran POE (Predict-Observe-Explain) terhadap Keterampilan Proses Belajar Fisika Siswa Pokok Bahasan Suhu dan Kalor. Indonesian Journal of Science and Mathematics Education, 1(1), 21-27.

Molinda, M. (2005), Instructional Technology and Media for Learning New Jersey Colombus, Ohio

Rahayuningsih, E. \& Dwiyanto, D. (2005). Pembelajaran di Laboratorium. Yogyakarta: Pusat Pengembangan Pendidikan UGM. 2002.

Sucilestari, R. \& Arizona, K. (2018). Pengaruh Project Based Learning pada Matakuliah Elektronika Dasar terhadap Kecakapan Hidup Mahasiswa Prodi Tadris Fisika UIN Mataram. Konstan Jurnal Fisika dan Pendidikan Fisika, 3 (1), 2635.

https://jurnalkonstan.ac.id/index.php/jurnal/arti cle/view/4

DOI: https://doi.org/10.20414/konstan.v3i1.4

Trianto, 2010. Model Pembelajaran Terpadu. Jakarta: Bumi Aksara. 